\title{
ぜい性材料の応力腐食特性を評価するための一方法
}

\author{
西田俊彦・植田邦義・林 国郎・西川友三 \\ (京都工芸繊維大学 工芸学部 工業化学科)
}

\begin{abstract}
ぜい性材料についての応力拡大係数 $\left(K_{\mathrm{I}}\right)$ とクラック速度 $(v)$ との関係を求めるための簡単な方 法についてのべた. 頂角 $120^{\circ}$ のェブロンノッチを導入したパイレックスガラス試片をスパン 90 $\mathrm{mm}$ の 3 点曲げで破壊した. 破壊試験は $0.2 \sim 0.001 \mathrm{~mm} / \mathrm{min}$ の間の一定変位速度の条件で，大気 中とトルエン中の室温で行った．KII は安定破壊の荷重一変位曲線をコンプライアンス解析するこ とによって求め, これと対応寸るvはズームアップレンズを取り付けたビデオカメラを使って測定 した. 得られた $K_{\mathrm{I}}$ とvの両対数プロットは大気中では領域 I の挙動を示し, トルエン中では領 域 I から領域I几の変化を示した. この試験法の特徴としては，(1) 試片の形状が単純である,

（2）試片が小さくても良い，(3) 安定破壊をさせやすい，（4）荷重方式が単純であり，高温におけ る測定にも適する，(5) ふん囲気の制御がしやすい，などの利点が考光られた。それ机えセラミッ ク材料の高温での応力腐食や劣化の問題を取り扱っていくうえで, この方法が従来の方法よりも実 験技術的にはより簡単な方法となるであろらと考えられた。

(1981 年 4 月 9 日受付)
\end{abstract}

\section{A Method for Evaluating the Stress Corrosion Characteristics of Brittle Materials}

\author{
Toshihiko NISHIDA, Kuniyoshi UEDA, Kunio HAYASHI and Tomozo NISHIKAWA \\ Department of Chemistry, Kyoto Institute of Technology
Matsugasaki, Sakyo-ku, Kyoto-shi 606
}

A simple method for measuring the relation of stress intensity factor $\left(K_{\mathrm{I}}\right)$ - crack velocity (v) of the brittle materials was studied. Pyrex glass specimens with chevron notch angle of $120^{\circ}$ were fractured by three-point bending technique with test span of $90 \mathrm{~mm}$. The fracture tests were carried out under a constant cross-head speed from 0.2 to $0.001 \mathrm{~mm} / \mathrm{min}$. in air with relative humidity of $50 \sim 58 \%$ or in toluene at room temperature. $K_{\mathrm{I}}$ were calculated from the compliance analysis of the load-time curves of the stable fracture, and the corresponding $v$ were measured by using a video camera with zoom up lens. The plot for $\log K_{\mathrm{I}}$ vs. $\log v$ in air showed the behavior of the region $I$ that the crack growth was attributable to a stress-enhanced chemical reaction between water and glass. On the other hand, the plot in toluene showed a transition from the regions I to II that the crack growth was controlled by the rate of transport of water to the crack tip. This method has the following advantages to measure $K_{\mathrm{I}}-v$ relation by three-point bending technique of ceramic samples with chevron notch: (1) the simplicity of specimen geometry, (2) small, inexpensive test specimens, (3) no precracking required for stable fracture, (4) easy measurement at high temperature because of simple compressive loading, and (5) easy environmental control. This should be, therefore, an easier method to obtain $K_{\mathrm{I}}-v$ relation than DoubleTorsion method etc. and serve to consider the stress corrosion and fatigue problem for ceramics at elevated temperature.

[Received April 9, 1981]

Key-wards : Stress corrosion, Stress intensity factor, Crack velocity, Pyrex glass, Chevron notch, Compliance analysis, Stable fracture

1. 緒司

固体材料が臨界末澫のある力学的環境下にある時, そ 
化機構の解明や寿命の予測に関して重要である ${ }^{11}$. そし てこの関係を求めるために Double torsion 法, Double cantilever beam 法などが考案され，ガラス ${ }^{2), 82}$ ，セラミ ックス ${ }^{4)}$,5) などへの適用が試みられてきた。しかしこれ らの試験法は, 方法の複雑さ, 試験片に要求されるデザ インと寸法, 試験に必要な治具の入手のしにくさ, など に種々の問題点もあって，例えば近年急速に発展してき た高温構造材料としての共有結合性セラミックスの高温 での応力腐食の問題など, $1000^{\circ} \mathrm{C}$ 以上の温度範囲にお 汀る測定を要求される場合には, 必ずしも最適な方法と は思われない。測定ふ九囲気の制御のしやすさ, 高温域 での測定のしやすさ，試料の作りやすさなどの要求を考 慮すると，より小さい試片による例えば 3 点曲げ法のよ うな単純な形式の圾験方法の開発が必要とされてきてい $3^{6}$.

本論文ではシェブロンノッチを導入したガラス試片に ついて, 変位速度一定条件下での 3 点曲げ破壞実験を行 い，安定破壞した場合の荷重一時間(変位) 曲線のコンプ ライアンス解析によって, 試片のクラック先端の $K_{\mathrm{I}}$ 值 と進展速度（ひ）との関倸を求めた。 その結果，この試 験方法が高温に扮活る構造材料の $K_{\mathrm{I}}-v$ 関係を求为る うえで, 前述のような測定上の問題点を解決していく一 つの方法となり得るであろらと考えられたので，その方 法と結果について報告する.

\section{2. 実 験 方 法}

市販のパイレックスガラスから $10 \times 10 \times 100 \mathrm{~mm}$ の直 方体に切り出したものを曲げ破壊測定用の試料とした。 ガラスは典型的な線形弾性体のモデル材料であり，乙か も透明なのでクラックの進展を直接目で観察できる利点 があった。試片は直方体各面の平行度を出寸ために平面 研削盤で形を整えた後，図1(a) に示すように刃厚 0.3 $\mathrm{mm}$ のダイヤモンド刃で 2 度切りして, 試片の長手方向

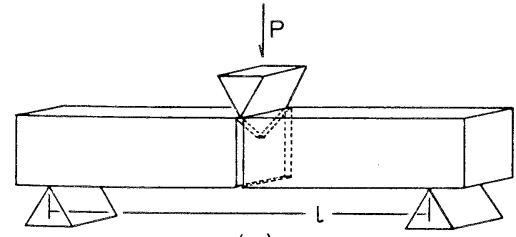

(a)

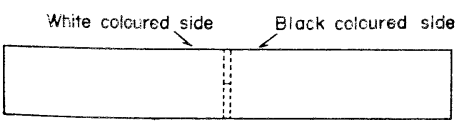

(c)

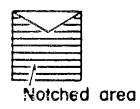

(b)
6 Fig. 1. Bend bar specimen with chevron notch.

a) Schematic configuration

b) Notch plane section

c) Top view of the specimen and video camera angle
の中央部に図 1 (b) に示すように断面の 1 辺を底辺と し，頂角 $120^{\circ}$ の二等辺三角形が残るようにシェブロン ノッチを入れた。

曲げ破壊試験はすべてスパン $90 \mathrm{~mm}$ の 3 点曲げ方式 により行い，その場合のクロスヘッドスピードは 0.2 $0.001 \mathrm{~mm} / \mathrm{min}$ の間の変位速度一定の条件を採用した.

$K_{I}$ の低い領域にわたっての測定を行うためには，変位 速度を非常に遅くするか, あるいは測定中変位を止め て, その時のクラック進展に伴う試片のコンプライアン ス変化を求めていく方法が望ましいと考えられる。しか し実際問題として高温測定では，測定系の熱的な定常化 がさずかしく，温度の摇乱による治具や測定装置の熱膨 張収縮の影響があって，変位をきちんと止める作業は事 実上不可能であるので，㐫程度のクロスヘッドスピー ドのもとで測定する技術を確立するほうが有用であろう と考えたからである. 曲げ破壊中の荷重は, 上部ナイフ エッジに取り付けた容量 $100 \mathrm{~kg}$ のロードセル（コンプ ライアンス : $\left.2 \times 10^{-8} \mathrm{~m} / \mathrm{N}\right)$ で検出し，その時閒変化を レコーダーに記録した。

曲げ破壞試験中に生ずるクラックの進展の様子を観察 するために，本研究ではビデオテープレコーダーを使用 した.すなおち曲げ破壞中, 試片と水平で長手方向約 $45^{\circ}$ の位置にズームアップレンズを取り付けたビデオカ メラを置いて，クラックの進展開始からノッチによって 切り残された三角形部分を分断するをでの全部の記録を 残した. 図 1 (c) に示した試片の平面図中に上述のビデ オカメラによる観察方向を知印で記入した. また同図中 に示されているように，観察方向と反対側の試片の側面 はノッチを境にして白と黒に塗り分けてクラックの進行 が観察しやすいように配慮した。

測定は $16^{\circ} \sim 18^{\circ} \mathrm{C}$ の大気中（相詨湿度 $50 \sim 58 \%$ ), 並 びに金属ナトリウムで脱水した $12^{\circ} \mathrm{C}$ のトルエン中で行 った.

\section{3. 結果亡考察}

線形弾性体が変形をらけた場合, 系全体に貯えられる ポテンシャルエネルギー（） は，変位（u）とクラッ ク面積 $(A)$ の関数として表され，それは試片に貯えら れたひずみエネルギー $(W(u, A))$ と装置に貯えられた ひずみエネルギー $\left(W^{*}(u, A)\right)$ との和として (1) 式で 表される.

$$
\pi(u, A)=W(u, A)+W^{*}(u, A)
$$

本実験のような曲げ試片のコンプライアンス $(\lambda(A))$ は装置のそれよりもずっと大きくなるので，簡単のため (1) 式の右辺第 2 項を無視して考えると

$$
\pi(u, A)=W(u, A)
$$

モードエのクラックが単位面積だけ増加する際に解放 されるポテンシャルエネルギー（ $g_{\mathrm{I}}$ ）は（3）式で定義 
されている。

$$
g_{I}\left(=\frac{1}{E^{\prime}} K_{I}^{2}\right)=-\lim _{\delta A \rightarrow 0} \frac{\delta \pi}{\delta A}=-\frac{\partial \pi}{\partial A}
$$

ここで $E^{\prime}$ はヤング率 $(E)$ とポアソン比 ( て, 平面応力状態では $E^{\prime}=E$, 平面ひずみ状態では $E^{\prime}$ $=E /\left(1-\nu^{2}\right)$ となる。 (2)，(3) 式と $W(u, A)=P u / 2$, $\lambda(A)=u / P$ という基本的な関係を組み合せると

$$
\begin{aligned}
K_{\mathrm{I}}{ }^{2} & =\frac{-\partial W(u, A) \cdot E^{\prime}}{\partial A}=\frac{u^{2} E^{\prime}}{2} \frac{\mathrm{d}}{\mathrm{d} A}\left(\frac{1}{\lambda(A)}\right) \\
& =\frac{u^{2} E^{\prime}}{2 \lambda(A)^{2}}\left(\frac{\mathrm{d} \lambda(A)}{\mathrm{d} A}\right)=\frac{E^{\prime}}{2}\left(\frac{\mathrm{d} \lambda(A)}{\mathrm{d} A}\right) \cdot P^{2}
\end{aligned}
$$

と変形され，結局 $K_{\mathrm{I}}$ は (5) 式で表される7),8)。

$$
K_{\mathrm{I}}=\sqrt{\frac{E^{\prime}}{2}\left(\frac{\mathrm{d} \lambda(A)}{\mathrm{d} A}\right)} \cdot P
$$

(5) 式を用いて曲げ破壊中のクラック先端の $K_{I}$ 值 を求めようとすると，曲げ破督条件をらまく設定して， 試片を安定破䘫させることが必要となる。

一般的にセラミックスのようなぜい性材料を普通に曲 げ変形していくと，その際に引っ張り忘力を受ける側の 表面近くに存在するクラック先端の $K_{\mathrm{I}}$ 值が $K_{\mathrm{I}}$ ○に達 して破壊を開始する時には，試片と装置に貯えられた弾 性エネルギーが焼結体を破燷するために要するエネルギ 一をはるかに上回ってしまっている，そしていったん破 壊が進行し始めると，クラック先端の $K_{\mathrm{I}}$ 值は $K_{\mathrm{I}}$ を 遥かに越えてし未うために，クラックの進展はますます 加速され，同時に余分の巣性エネルギーが音の発生や試 片の飛散を招くことになる? (不安定破壊)。これに対し て,本研究で採用したシェブロンノッチをもつ試片では, ノッチによって切り残された二等辺三角形部分の頂点に 応力を集中させることができるので，低荷重でクラック の進展が開始し，しかもその場合のクラックは自然発生 的な鋔いもの (zero volume crack) となる゙．このこと
は曲げ変形中の試片への弾性エネルギーの蓄積を防ぐた めの極めて重要な因子である。そしていったん破壊が開 始すると，クロスヘッドスピードを極端に速くしない限 りは，試片の破断まで $K_{\mathrm{IC}}$ 以下での河っくりした破壊 を行わせることが可能となる (安定破㙥)。実験方法の ところで示した本実験のシェブロンノッチ角, クロスへ ッドスピード，試片の寸法，並びに 3 点曲げエッジの下 側スパン間距離などの測定条件は，上述のような安定破 壊のための必要条件を考慮したうえで, 種々の予備実験 を行った結果決めたものである。

本実験で得たパイレックスガラス試料についての安定 破壇の荷重一時間曲線の一例を図 2 に示す，測定は温度 $17^{\circ} \mathrm{C}$ ，相対湿度 $55 \%$ の大気中で行ったものである。測 定桑件に関寸る詳細は図中に記入した。 また图 3 は，図 2 の試片の破填中におけるクラック進展状況をビデオに 收録したものの中から、クラックの進展開始から破断完 了㨁前までの順次写真に撮り直して並べたすのである。 先に図 1 (c) について説明したように，試片のビデオカ

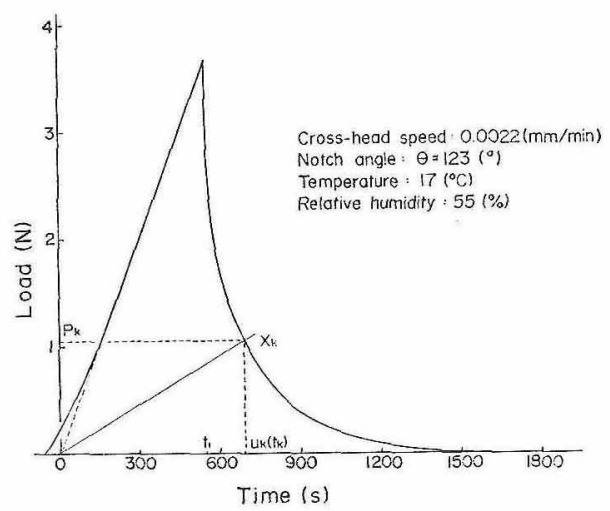

Fig. 2. An example of load - time curve of pyrex glass.
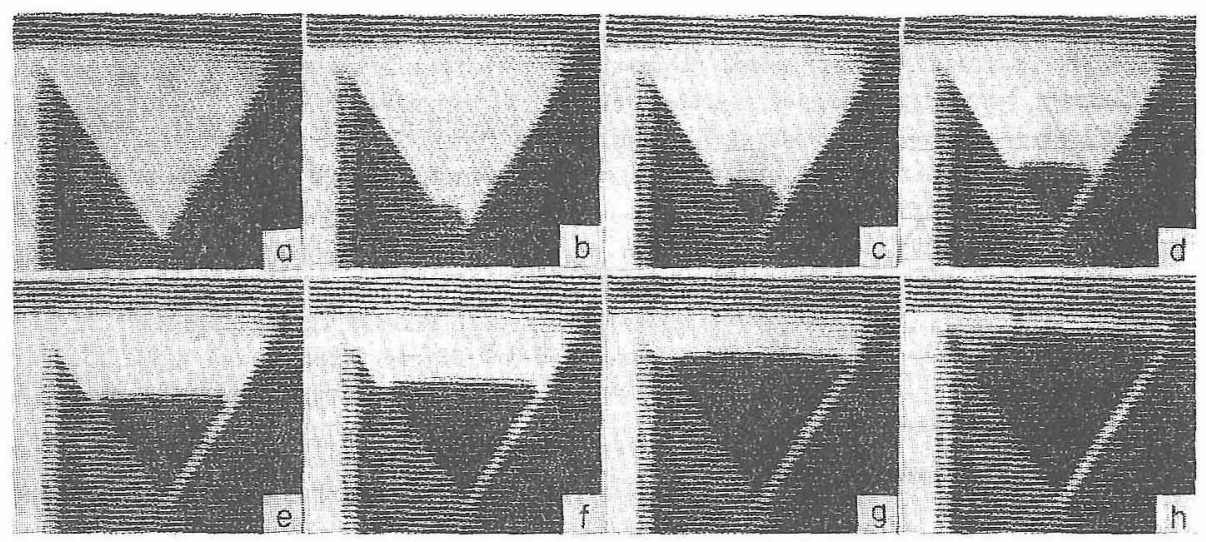

Fig. 3. Photographs of crack propagation in the bend bar specimen shown in Fig. 2. White part is area to be broken, and black part is cracked area. a) is before crack initiation and the time after crack initiation of $\mathrm{b}) \sim \mathrm{h}$ ) are $1,6,10,80,120,250$ and $900 \mathrm{sec}$, respectively. 
メラと反対側の側面がノッチを境にして白黒に塗り分け てあるので，写真では破壊していない部分は白色，破壞 した部分は黒色にみえる.クラックは必ずしもノッチに よって切り残された二等辺三角形部分の頂点から開始す るとは限らなかった．たとえば写真に示された例では頂 点より少し左側へずれた部分に破壊の起点がみられる. これはノッチ加工の際のダイヤモンド刃によって導入さ れる微細なきずの存在する部分で局所的に $K_{\mathrm{I}}$ 值が上 昇するために生ずる現象である。しかしいずれの場合も クラックの進展とともにその先端が直線状となり, 平面 応力状態が満足されていくことが認められた。

このような破壊の進行をした場合のクラック長さ (a) は，二等辺三角形をしたクラック部分の頂点からクラッ ク先端へ下した垂線の長さで与えられるから，テレビ画 面より読み取った $a$ と，破壞開始後の時間 $\left(t_{\mathrm{k}-\mathrm{i}}\right)$ (図 2 の時間軸参照）を図4のようにプロットして曲線関係 を求めておき，任意の時間 $\left(t_{\mathrm{k}}\right)$ における接線のこう配 としてその時のクラック速度 $\left(v_{\mathrm{k}}\right)$ が得られる. 一方, うクラック先端の応力拡大係数 $\left(K_{\mathrm{I} \mathrm{k}}\right)$ は (5) 式を使っ て以下のようにして求められる。図 2 の荷重一時開曲線 （変位速度を一定としているので，時間軸は変位軸とし

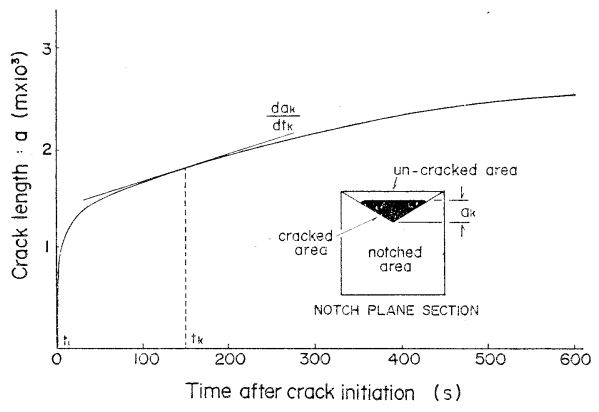

Fig. 4. Crack length - time after crack initiation relationship obtained from the photographs as shown in Fig. 3.

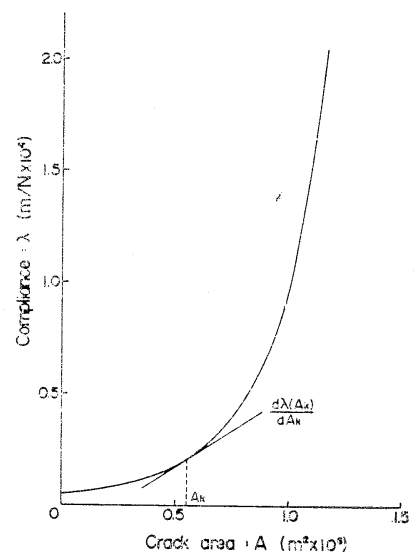

Fig. 5. Compliance - crack area relationship obtained from Fig. 2 and Fig. 4.
て読み代えることができる）の原点（ $u, P, t$ ともに0 とみなせる点）から曲線に刘して任意に引いた直線との 交点を $\mathrm{X}\left(u_{\mathrm{k}}, P_{\mathrm{k}}\right)$ としたとき，X点における試片のコ ンプライアンス $\lambda\left(A_{\mathrm{k}}\right)$ は原点からのこう配の逆数 $\left(u_{\mathrm{k}} / P_{\mathrm{k}}\right)$ である。またその時，同時に観察しているビデ オの画面から得られるクラック長さ $\left(a_{\mathrm{k}}\right)$ と, 試片の， ッチ角 $(\theta)$ の関数としてクラック面積 $\left(A_{\mathrm{k}}\right)$ が $(6)$ 式 で与えられる。

$$
A_{\mathrm{k}}=a_{\mathrm{k}}{ }^{2} \tan \frac{\theta}{2}
$$

この両者の関係を破壞の開始から完了までの閒に逐次 求めて図 5 のようにプロットしておくと（5）式中の $\mathrm{d} \lambda(A) / \mathrm{d} A$ の值はこの曲線の $A_{\mathrm{k}}$ に扮汀る接線のこう 配として得られ，その時の $P_{\mathrm{k}}$ と，試片の $E^{\prime}$ (図 2 よ り分るように破壞が少し進行すると試片には平面応力状 態が成立するので， $E^{\prime}=E$ としてパイレックスガラス に関する文献值 ${ }^{10)} E=7.15 \times 10^{10} \mathrm{~N} / \mathrm{m}^{2}$ を計算に使用し た）を代入すると $K_{\mathrm{I} \mathrm{k}}$ が求められる。図 4 ，図 5 にお いて接線のこう配を得る作業は，曲線上の約 100 点の座 標を読み，その中の連続した 7 点を放物線回帰したのち

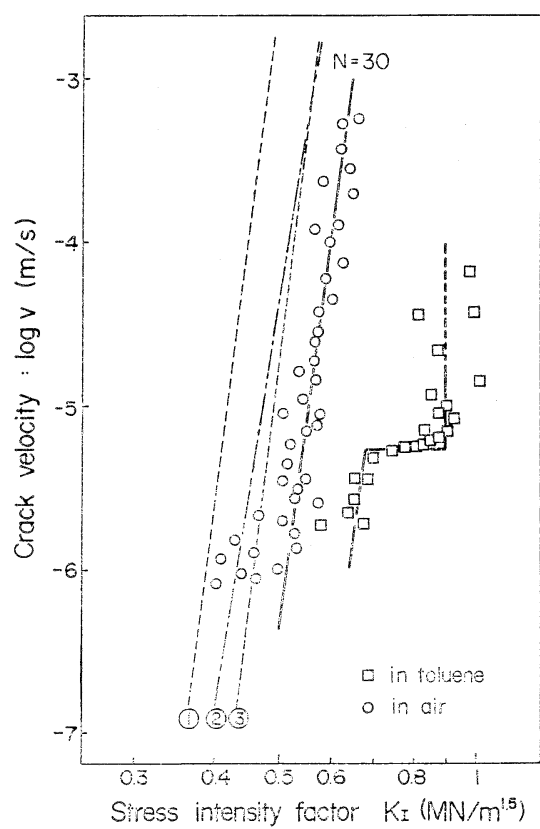

Fig. 6. Crack velocity-stress intensity factor relationship for pyrer glass at room temperature.

-.......(1) Shetty et al. ${ }^{12)}$ measured by D.T. in water at $23^{\circ} \mathrm{C}$

(2) Wiederhorn et al. ${ }^{11)}$ measured by D.C.B. in water at $25^{\circ} \mathrm{C}$

(3) Shetty et al. ${ }^{12)}$ measured by D.C.B. in water at $23^{\circ} \mathrm{C}$

Present work in air with relative humidity of $50 \sim 58 \%$ at $16 \sim 18^{\circ} \mathrm{C}$ Present work in toluene at $12^{\circ} \mathrm{C}$ 
中央の点で微分を取って行った.

図 6 にパイレックスガラスの大気中並びにトルエン中 での $K_{1}-v$ 関係を両対数プロットで示した. 同図中に は他の試験方法で得られてきた測定結果と比較できるよ うに，パイレックスガラスに関してなるべく大気中の実 験条件に近いと思わ机る報告值 ${ }^{11)}{ }^{12)}$ を選んで，参考の ために記入した. 曲げ試片のコンプライアンス解析によ って得た值は幾分 $K_{\mathrm{I}}$ が大きく（あるいはvが小さく） 測定されている傾向がみられる. しかし他の方法による 測定結果にも方法の違いによる差がかなりあることを考 慮すると, 現段階においては, 試料, 測定条件, 測定方 法，荷重方式などの差が集積された結果現れたもので あろらと考えられる。 また同図のプロットは大気中 4 本，トルエン中 2 本の試片についての測定結果を重ねて 記してある(図の繁雑さを避けるためにプロットの数は 約 $1 / 10$ に省略した). 曲げ破壞の際の変位速度や試片を 変えても測定の再現性は極めて良かった，変位速度を速 く(0.2 0.1 mm/min) 選ぶとvは $10^{-3} \sim 10^{-5} \mathrm{~m} / \mathrm{s}$, 遅 く(0.05 0.001 mm/min) 選ぶと $10^{-4} \sim 10^{-6} \mathrm{~m} / \mathrm{s}$ の範 囲の測定が行いやすかった. 曲げ方式であるので，vの 遅い部分の測定を精密に行うためには破断寸前付近での $a$ の変化を正確に読む必要があった. 本研究では前述の ビデオと併用して写真撮影も試みたが，クラック面に対 して斜めの方向から観察する方式をとった関係もあって か, ひが $10^{-7} \mathrm{~m} / \mathrm{s}$ オーダーの測定はできなかった.

ガラスの応力腐食が水分によって促進されることに関

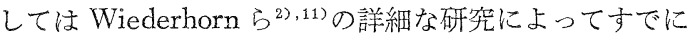
報告されており，腐食成分である水との反応がvを律速 する領域 (I), 水のクラック先端への抎散が $v$ を律速 する領域（II)，並びに $K_{\mathrm{I}} \mathrm{C}$ 近くで腐食と機械的な破

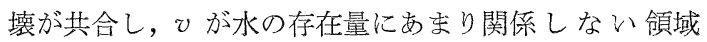
(III) の存在することが確からられてきた. 図6の大気 中のデータは腐食成分の水が多量に存在するために $K_{I}$ の高いところまで領域（I）が観察されたものと考えら れる.ちなみにこの場合の両対数プロットのこう配 $(N)$ は 30 で, パイレックスガラスについて他の方法で測定 されてきた值 ${ }^{11,12)}$ と良く一致している. なお $v か ゙ ~ 10^{-6}$ $\mathrm{m} / \mathrm{s}$ 付近に㧍けるプロットが $K_{I}$ の小さい方へ直線関 係からずれる傾向にあるが，aの測定精度の不足，ある いは試片の自重による $P$ の過小評価などの影響が現れ ているものと考える、直線のこう配は測定精度を考慮し てvが $10^{-3} \sim 10^{-5} \mathrm{~m} / \mathrm{s}$ 付近のデータに重みを置いて 求めたものである. 一方, トルエン中のデーターは水が 少ないために $v=10^{-5} \mathrm{~m} / \mathrm{s}$ より少し下のところで領域 （I）から領域（II）への移行が認められる. トルエン は使用前に一尽夜金属ナトリウムによる脱水処理を行っ た.トルエン中の水分量の定量は行わなかったが，測定 中にも金属ナトリウムからの水素ガスの発生が続いてい
たことを考慮すると，ある程度の水分が存在していたと 考えられる. 更に本実験の結果からは領域（II）加ら領 域（III）への明確な移行は認められず，KIC あるいは それ以上のところ (パイレックスガラスの $K_{\mathrm{I}}$ はせい ぜい $0.8 \mathrm{MN} / \mathrm{m}^{3} / 2$ 程度であろう) でデータがばらつき ながらvの速い不安定破壞に移行していくように思わ れる. 曲げ破填方式であるので， $K_{\mathrm{I}}$ に近い範囲での 測定注 3 (b) (c) のような忘力状態の乱れた条件下で 行われがちなことがあるいは原因しているのかも知机な w。

以上，本研究ではガラスをモデル材料として曲げ破壊 試験を行い，得られた安定破壊の荷重一時間 (变位) 曲 線をコンプライアンス解析することによって $K_{\mathrm{I}}$ 一の 関係を求めた。 ガラスは透明材料なので $a$ (または $A$ ) の時間的変化を直接読み取ることができた. 一方，七ラ ミックス材料の大部分は不透明材料であり, しかも高温 測定になると本実験で行ったと同じ方法をそのまま適 用できない。しかし解析に用いた試片のコンプライアン ス（ג）は， $E^{\prime}$ と試片及びクラックの形状に関する係数 （I）を用いて $\lambda=1 / E^{\prime} I$ で表現される性質のものであ る. 仮にガラスを使って，I がセラミック材料とほとん ど等しくなるような実験条件（試片の形状，寸法，， ッチ角など）を設定することが可能とすれば，七ラミッ クスの荷重一時間曲線と，ガラスであらかじ的求めてお いた $\mathrm{d} A-\mathrm{d} \lambda(A)$ の関係を $E^{\prime}$ の差で補正した曲線, 並 びにガラスで求めた $a-t_{\mathrm{i}-\mathrm{k}}$ の関係を使って, vと $K_{\text {I }}$ の算出が可能になる. 本論文で述べたと同じ方法で $4 \times$ $4 \times 50 \mathrm{~mm}$ の窒化ケイ素焼結体を $42 \mathrm{~mm}$ のスパンで曲 げ破壞し，再現性の良い荷重一時間曲線が得られること が著者らの研究室で既に分ってきている ${ }^{13)}$. 試片を小さ くできれば高温測定において，温度分布の均一化やふん 囲気の制御は格段に容易になる，更に測定方法の単純さ や一般に広く使用されている 3 点曲げ破壊用の試験機 や治具をほぼそのまま流用できる利点などを考慮すれ ば，曲げ破壊曲線のコンプライアンス解析法は，七ラミ ックスのようなぜい性材料の応力腐食や劣化の問題を取 り扱らための一つの方法となる可能性をもつと考えられ る.

\section{4. 総 括}

ぜい性材料の応力腐食や劣化の機構を推定するらえで 重要とされているクラック先端での応力拡大係数 $\left(K_{\mathrm{I}}\right)$ とその時のクラック速度 (v) との関係を求めるためのよ り簡単な試験方法について述べた。パイレックスガラス をモデル材料として，頂角 $120^{\circ}$ のシェブロンノッチを 導入した後，スパン $90 \mathrm{~mm}$ の 3 点曲げ方式で，0.2 $0.001 \mathrm{~mm} / \mathrm{min}$ の範囲のクロスヘッドスピード一定の条 件下でゆっくりと破壊させた．そしてビデオカメラで観 
察したクラック進展長さ（a）と曲げ破壊の荷重一時間曲 線を使ってコンプライアンス解析により $K_{\mathrm{I}}-v$ の関係 を求めた。

パイレックスガラスについて $K_{\mathrm{I}}$ 一 の関係を両対数 プロットすると，大気中の測定值は水による化学反応が 応力腐食を律速するといわれる領域（I）の挙動がみら れた.この場合の両対数プロットのこう配 $(N)$ は 30 であった、いっぽうトルエン中では領域（I）から水の クラック先端への拡散が律速となる領域 (II) 一の遷移 が認められた。

シェブロンノッチを導入した試片の曲げ破壞試験で は，1）試片の形状が小形，単純で，しかも作りやすい， 2) あらかじめクラックを導入して沶かなくても安定破 壊させやすい，3）通常の曲げ破壞方式が適用できるの で高温測定やふん囲気制御が簡単である，などの利点が あげられる、それゅえこの方法はセラミック材料の高温 での応力腐食や劣化の問題を取り扱らうえで有力な手段 となる可能性をもつと考えられた。

謝辞 本研究の考察をすすめるに当たって京都工芸繊維 大学 工芸学部 生産機械工学科助教授斉藤憲司博士に熱心な御 討論をいただいた。記して感謝の意を表する。

\section{文献}

1）㝘業協会編集委員会講座小委員会編 “セラミックスの機 械的性質” 技報堂 (1979), p. 49-57, p. 96-99, p. 15562.

2) S.M. Wiederhorn, J. Am. Ceram. Soc., 50, 407-14 (1967).

3) K. Schünert, H. Umhauer and W. Hlemm, "Fracture1969" Ed. by P.L. Pratt, Chapman and Hall Ltd., London (1969), p. 476-82.

4) A.G. Evans, J. Mater. Sci., 7, 1137-46 (1972).

5) R.K. Govila, J. Am. Ceram. Soc., 63, 319-26 (1980).

6) T.T. Shin and J. Opoku, Eng. Fract. Mech., 12, 479-98 (1979).

7）岡村弘之, “線形破壊力学入門”培風館（1978）, p. 4964.

8) A.G. Evans, "Fracture Mechanics Determination" Ed. by R.C. Bradt, D.P.H. Hasselman and F.F. Lange, "Fracture Mechanics of Ceramics, Vol. 1" Plenum Press (1974) p. 41-42.

9) D. Munz, R.T. Bubsey and J.L. Shannon Jr., J. Am. Ceram. Soc., 63, 300-05 (1980).

10) S. Spinner, ibid., 39, 11.3-18 (1956).

11) S.M. Wiederhorn and L.H. Bolz, ibid., 53, 543-48 (1970).

12) D.K. Shetty, A.V. Virkar and M.B. Harward, ibid., 62, 307-09 (1979).

13) 武井喜樹, 京都工芸繊維大学卒業論文 (1981).

論 文・Paper

\title{
ニチタン酸カリウム繊維の水和と誘導体
}

\author{
藤 木 良 規・大 坂 俊 明 \\ (無機材質研究所)
}

二チタン酸カリウム $\left(\mathrm{K}_{2} \mathrm{Ti}_{2} \mathrm{O}_{5}\right)$ 瀻維をメルト法により育成した. $\mathrm{K}_{2} \mathrm{CO}_{3}$ と $\mathrm{TiO}_{2}$ の化学量論比 組成の混合物を $1100^{\circ} \mathrm{C}$ で 30 分間溶融し, 底を水冷している他の金属容器の中一流し出して繊維 状集合体としてすみやかに結晶化させた。緘維分離は結晶化体を水中に浸漬して行った.この水和 反応はカリウムイオンの溶出を伴って水和相 $\mathrm{KHTi}_{2} \mathrm{O}_{5} \cdot n \mathrm{H}_{2} \mathrm{O}$ を形成した. 水和相は $900^{\circ} \mathrm{C}$ 付近 で熱処理すれば四チタン酸カリウム繊維に移行する。また，二チタン酸カリウム繊維を温水及び沸 騰水で処理後 $900^{\circ} \mathrm{C}$ 付近で熱处理すれば六チタン酸カリウム繊維, 酸水溶液で処理すれば結晶質于 タン酸 $\left(\mathrm{TiO}_{2} \cdot n \mathrm{H}_{2} \mathrm{O}\right)$ 繊維などの誘導体を合成することができる. (昭和 56 年 4 月 13 日受付)

\section{Hydration and Derivatives of Potassium Dititanate Fibers}

\author{
Yoshinori FUJIKI and Toshiaki OHSAKA \\ (National Institute for Research in Inorganic Materials
}

Potassium dititanate $\left(\mathrm{K}_{2} \mathrm{Ti}_{2} \mathrm{O}_{5}\right)$ fibers were grown by the melt method. A mixture of stoichiometric composition consisting of $\mathrm{K}_{2} \mathrm{CO}_{3}$ and $\mathrm{TiO}_{2}$ was melted at $1100^{\circ} \mathrm{C}$ for $30 \mathrm{~min}$, 